\title{
Does Zero-leverage Policy Increase Inefficient Investment? From The Perspective Of Lack Of Bank Creditors
}

Wanli Li, Xi' an Jiaotong University \& Shanghai University of International Business and Economics, China Zhen Huang, Xi' an Jiaotong University, China

Weiwei Gao, Xi'an Jiaotong University, China

\begin{abstract}
Using a sample of up to 12023 firm-year observations across 2358 individual firms from 2007 to 2013, this paper examines whether zero-leverage policy increases firms' inefficient investment from the perspective of lack of bank creditors. Due to the lack of bank creditor monitoring, zero-leverage policy leads to more serious information asymmetry and agency problems, which are the two types of frictions that affect investment efficiency. The empirical results show that zero-leverage policy indeed increases inefficient investment. Furthermore, we test whether external monitoring helps to mitigate the effects of zero-leverage policy on inefficient investment. Our findings suggest that the sensitivity between zero-leverage policy and inefficient investment will be lower in firms with strong external monitoring. Overall, the zero-leverage policy seems to be a key determinant of inefficient investment.
\end{abstract}

Keywords: Zero-leverage Policy; Lack of Bank Creditor; Inefficient Investment

\section{INTRODUCTION}

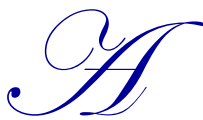

s we all know, bank financing can bring certain tax savings, reduce the free cash flow for the pressure of payments (Jensen, 1986; Stulz, 1990), and encourage managers to work hard. Besides, it is the main source of finance for Chinese firms. However, more and more listed firms choose zeroleverage policy in recent years. From 1962 to 2009, about 10.2\% of large public US firms have zero debt (Strebulaev and Yang, 2013). In China, the number of zero-leverage firms has increased from 49 in 2000 to 505 in 2012 , and firms with no debt has account for $20.73 \%$ in 2012, which are consistent with the international zeroleverage evidence provided by Bessler et al. (2013). The international phenomenon that so many firms eschew any debt, which can't be explained by both the trade-off theory and the pecking order theory, is called the zero-leverage puzzle (Strebulaev and Yang, $2013^{\mathrm{I}}$ ). Why do so many firms choose zero-leverage policy giving up the benefits of leverage financing?

The most significant difference between zero-leverage firms and leverage firms in corporate governance is whether bank creditors exist. The lack of bank creditor monitoring in zero-leverage firms has certain effects on firms' behavior. Hadlock and James (2002) show that bank creditors help to alleviate asymmetric information problems. In addition, Gilson et al. (1990) argue that creditor monitoring can substitute for ineffective board governance in financially distressed firms. Prior research has also shown that the monitoring role of bank creditors can mitigate agency conflicts between shareholders and managers to some extent (Ang et al., 2000). A large body of literature shows that information asymmetry and agency problems are two main types of frictions that affect inefficient investment(Cutillas Gomariz and Sánchez Ballesta, 2014; Hovakimian, 2011; Chen et al., 2011), so the increase of asymmetric information and agency conflicts would further result in firms' inefficient investment. Therefore, does zero-leverage policy increase inefficient investments because of lacking bank creditor?

Recent studies on zero-leverage policy are mainly focused on firms' motivations for choosing zeroleverage policy. Our study instead tries to break the current research horizon and consider what effects zero-leverage 
policy has on firms' capital investment. The main purpose of this paper is to figure out whether zero-leverage firms without bank creditors have more inefficient investment. Our study, which is focused on the lack of bank creditors in zero-leverage firms, is the first one to empirically examine what effects zero-leverage policy has on inefficient investments. Because we want to test whether the absence of bank creditors monitoring are the main determinants of zero-leverage firms' inefficient investment, we introduce institutional ownership to examine whether the inefficient investment is mitigated by the increase of external monitoring.

In sum, our paper contributes to the literature in three ways. First, our evidence enriches the extant literature on zero-leverage firms. Our study tries to examine the investment efficiency of zero-leverage firms from the perspective of economic consequences, while previous studies mostly investigate firm-level fundamentals and firms' motivations for choosing zero-leverage policy. Our paper thus fills this important gap in the literature examining the role of zero-leverage policy in a very different setting. Specifically, we deliberately "turn two dials at once" by moving from developed countries to emerging markets and by moving from firms' motivations for choosing zero-leverage policy to its economic consequence. Second, our findings enhance the understanding of firm's zero-leverage policy from the monitoring role of bank creditors. We focus on the difference, whether bank creditors exist, between zero-leverage firms and leverage firms in corporate governance while many studies only examine the characteristics and the quality of corporate governance in zero-leverage firms, ignoring the lack of bank creditor monitoring. Finally, this paper contributes to the limited literature on zero-leveraged firms by addressing the previously unexplored question: does zero-leverage policy without bank creditors increase inefficient investment?

The remainder of the paper proceeds as follows. Section 2 reviews the existing literature on investment efficiency and how zero-leverage policy without bank creditor monitoring affects investment efficiency, and develops our testable hypotheses. Section 3 mainly focuses on the sample and data, measurements of variables and describes empirical models in detail. The empirical results and discussion are presented in Section 4 and robustness tests in Section 5. Section 6 presents the main conclusion of this paper.

\section{LITERATURE REVIEW AND HYPOTHESES}

\section{Determinants of Investment Efficiency}

According to the Modigliani-Miller (1958) paradigm, investment opportunity is the only factor driving firms' investment policy. Under this theory, firms should invest all the projects with positive net present value (NPV) until the marginal benefit equals the marginal cost. However, firms' actual investment may deviate from the optimal level due to some capital market frictions, producing underinvestment or overinvestment problems. Information asymmetry and agency problems are two types of frictions that affect inefficient investment.

On the one hand, information asymmetry between managers and investors lead to underinvestment. Having information advantage about firms' prospects, managers may try to time capital issuances to sell overpriced securities. If it is learnt by investors, they may ration the capital or raise its cost to avoid this, which may lead to the rejection of some profitable projects due to financial constraints (Biddle et al., 2009), resulting in underinvestment. Therefore, the adverse selection caused by information asymmetry becomes an important factor affecting the firm's investment efficiency.

On the other hand, ideally speaking, managers should always maximize the shareholders' interests, however agency models suggest that managers are self-interested and may not always act in the interest of shareholders (Jensen and Meckling, 1976), which may lead to inefficient investment. The discrepancy of interests between shareholders and managers may cause managers to maximize their personal interests by making investment not suitable for shareholders (Jensen and Meckling, 1976), thus leading to overinvestment to build managerial empire (Hope and Thomas, 2008).

The discussion above suggests that information asymmetry and agency problems can reduce capital investment efficiency by giving rise to frictions that can lead to overinvestment or underinvestment. Against this backdrop, we examine the effect of zero-leverage policy without bank creditors on inefficient investment, and analyze how zero-leverage policy affects the investment behavior both directly and indirectly. 


\section{The Role of Bank Creditor Monitoring}

The most significant difference between zero-leverage firms and leverage firms in corporate governance is whether there are bank creditors. Prior studies suggest that bank creditors, as monitors, play an important role in corporate lending (Wang and Xia, 2014). They can examine firm quality and discipline them through creditor rights enforcement (Qian and Yeung, 2014). We present the effectiveness of bank creditor monitoring in corporate governance.

Why are bank creditors efficient in monitoring borrowers? First, the unique bank monitoring mechanism reduces credit risk by prior selection, daily monitoring and post-supervision. Bank creditors perform monitoring activities to avoid borrowers' earning management, thereby reducing credit risk (Ahn and Wooseok, 2009). Second, the deposit relationship between bank creditors and borrowers is another reason. Through deposit services, bank creditors may possess timely and exclusively access to the borrower's private information including the cash flows (Ahn and Wooseok, 2009). Therefore, bank creditors can effectively monitor the borrowers. Third, bank creditors can play the monitoring role by directly participating in a firm's decision-making process. For example, they can be a member of borrowers' board of directors.

A large body of theoretical research explicitly analyzes bank creditor's monitoring. Two major theories, banks are involved as delegated monitors (Diamond, 1984) or information producers (Leland and Pyle, 1977; Campbell and Kracaw, 1980), are proposed to explain the bank creditors' "specialness". Diamond (1984) develops the delegated monitoring theory that bank has a net cost advantage relative to direct lending and borrowing. Fama (1985) shows that bank creditors enjoy a unique role as inside lenders because they obtain private information through their ongoing deposit relationship with the firm. These arguments indicate that bank debt is special among public debt and other financing sources (Diamond, 1984; Fama, 1985; James and Smith, 2000 ). Furthermore, Gilson et al. (1990) argue that creditors' monitoring can substitute for ineffective board governance in financially distressed firms. Ahn and Wooseok (2009) examine the bank creditors' role in corporate governance in the US by investigating the effect of bank creditors' monitoring on the borrowers' earnings management, which is consistent with the study that banks are substituted monitors for some internal corporate governance mechanisms (Byers et al., 2008). In addition, banks play an important role in examining firm quality and disciplining them through creditor rights enforcement (Qian and Yeung, 2014).

Finally, prior research shows that bank creditor plays an important role in corporate governance, which can mitigate agency conflicts between shareholders and managers to some extent, reduce the agency costs (Ang, et al., 2000) and alleviate information asymmetry(Hadlock and James, 2002). However, the agency conflicts and information asymmetry may increase with the lack of bank creditors' monitoring in zero-leverage firms, thereby resulting in the inefficient investment.

\section{Investment Efficiency and Zero-leverage Policy}

In practice, bank creditor monitoring can reduce firms' inefficient investments, so zero-leverage firms may tend to encounter more inefficient investment problems due to lacking bank creditors. We focus on bank creditor's monitoring role to analyze how zero-leverage policy affects investment efficiency.

We focus on the difference between zero-leverage firms and leverage firms in corporate governance and predict that the lack of bank creditors in zero-leverage firms will bring some changes to corporate governance and the relationships among various stakeholders. Based on this, we find that there are several mechanisms through which zero-leverage policy can increase inefficient investment.

The lack of bank creditors in zero-leverage firms also increases information asymmetry and agency problems, thereby ultimately leading to these firms' inefficient investment. First, the information asymmetry between managers and shareholders leads to inefficient investment when cash flow is low because managers cannot convince shareholders that cash flow is insufficient to meet all positive NPV opportunities (Stulz, 1991). Hadlock and James (2002) suggest that banks help alleviate information asymmetry, and that firms weigh these information benefits against a wide range of contracting costs when choosing banking financing, which can increase investment 
efficiency. Consistent with this argument, many researchers have attributed positive bank loan announcement effects to the hypothesis that banks help solve their borrowers' asymmetric information problems (Kang and Liu, 2008). Loan announcements provide information to the market about how bank invests to generate cash flows (Kang and Liu, 2008). Second, Ang et al. (2000) show that the agency costs of private firms monitored by banks are lower and conclude that bank creditor monitoring adds value. In addition, bank debt payments can force managers to pay out cash flow and hence reduce investment. As a result they can reduce free cash flow (Jensen, 1986; Stulz, 1990), encourage managers, and mitigate the agency conflicts between shareholders and managers by making enterprises face regular repayment pressure. Therefore, debt can potentially mitigate the misaligned incentives and constrain overinvestment by reducing free cash flows and increasing creditors' monitoring (Jensen, 1986; Zwiebel, 1996; Harvey et al., 2004; Paligorova and $\mathrm{Xu}, 2012$ ).

As discussed above, bank financing is a tool not just for financing, but also for corporate governance. Bank creditors have incentives and motivations to monitor operating performance. Ahn and Wooseok (2009) suggest that bank creditors perform special monitoring activities at lower costs because (i) banks are delegated monitors (Diamond, 1984), and (ii) banks have informational advantages (Fama, 1985). By screening and maintaining close relationships with borrowers, banks can obtain a competitive advantage over other capital market participants in collecting information about borrowers (Kang and Liu, 2008). Moreover, Dewatripont and Tirole (1994) predict that debt-holder suffers after bad performance and equity-holder benefits after good performance. This leads to a partial congruence in interests between managers and equity-holders, and difference in interests in managers and creditors. In addition, the stricter monitoring and more restrictive covenants accompanying bank debt help to mitigate the costs associated with shareholder-creditor conflict (Shepherd et al., 2008). Therefore, controlling the bank debt issue can bring down the inefficient investment including overinvestment derived from managers' self-interested behavior and underinvestment caused by information asymmetry between managers and investors. In consequence, without bank debt, zero-leveraged firms may face higher level of inefficient investment risks.

Hence, given the argument above, the following Hypothesis 1 can be assumed:

H1: Zero-leverage firms without bank creditors have more inefficient investments than leverage firms.

\section{Other External Monitoring}

Does other external monitoring mechanism influence the relationship between zero-leverage policy and inefficient investment? If the lack of bank creditor monitoring leads to the increase of firms' inefficient investment, we want to further examine whether such effects can be mitigated by the other external monitoring. Here we take institutional investors as substitution.

The role of institutional investors in external corporate monitoring has attracted wide attention and recognition. The institutional investors can pressure managers to orient their decisions towards shareholders' interests (Gillan and Starks, 2000). What's more, due to the high monitoring costs, only large shareholders such as institutional investors have strong incentives and capabilities to devote resources to monitoring (Grossman and Hart, 1980; Cornett et al., 2007), which is consistent with the view that large shareholders may have a greater incentive to monitor managers than those having little wealth invested in the firm (Shleifer and Vishny, 1986). And institutional investors can urge managers to focus more on corporate performance rather than opportunistic behavior, therefore mitigating the agency conflicts between shareholders and managers (Cornett et al., 2007; Lin et al., 2011). In addition, Bathala et al., (1994) argue that both debt-holders and institutional investors are considered to be important mechanisms for controlling managerial behavior and mitigating the agency problems. As a result, we can further investigate how institutional ownership influences firm's investment efficiency as well as its impact on the relation between zero-leverage policy and inefficient investment. We predict that the effect of zero-leverage policy on inefficient investment becomes weaker with the increase of other external monitoring.

Based on above arguments, our second hypothesis is as follows:

H2: The sensitivity between zero-leverage policy and inefficient investment becomes weaker when other external monitoring increases 


\section{METHODOLOGY AND DATA}

In this section, we describe our sample and data, variable measurements, and the model specification.

\section{Sample and Data}

Our sample comprises unbalanced panel data in Shanghai and Shenzhen Stock Exchanges from 2007 to 2013. The reasons for choosing this period are: (1) the yearly number of zero-leverage firms is less than 100 (except in 2006) before 2007 and is less than $10 \%$ of the total firms, which shows zero-leverage policy in these firms may not be the result of managerial choice; (2) the listed firms adopt the new accounting standards in 2007. The data under new accounting standards would have better comparability.

The data in this paper comes from CSMAR (China Stock Market Trading Research Database) and Wind Database, which are both extensively used in China. We exclude financial firms because their investment behaviors are different from those of non-financial firms. Firm-year observations with incomplete data are deleted. Outliers that may influence outcomes are excluded by $1 \%$ of two tails for each regression observation. Finally, our sample selection process produces a sample of up to 12023 firm-year observations across 2358 individual firms.

\section{Variable Measurements}

\section{Dependent Variable: Proxy for Inefficient Investment}

Conceptually, inefficient investment means undertaking projects with negative net present value or giving up projects with positive net present value. Consistent with prior research (e.g., Richardson, 2006 ${ }^{[33]}$ ), we measure inefficient investment as deviations from expected investment using a model that predicts investment as a function of growth opportunities, leverage, the level of cash, firm age, firm size, return on assets and prior firm level investment.

$$
\begin{aligned}
& \text { Invest }_{i, t}=\alpha_{0}+\alpha_{1} \text { RevGrowth }_{i, t-1}+\alpha_{2} \text { Lev }_{i, t-1}+\alpha_{3} \text { CashHoldings }_{i, t-1}+\alpha_{4} A G E_{i, t-1} \\
& +\alpha_{5} \text { Logsize }_{i, t-1}+\alpha_{6} \text { ROA }_{i, t-1}+\alpha_{7} \text { Invest }_{i, t-1}+\sum \text { Year }+\sum \text { Industry }+\varepsilon
\end{aligned}
$$

where the dependent variable Invest is firm's new investment expenditure. The variable RevGrowth is the growth opportunities. The expected investment on new projects will be an increasing function of growth opportunities. In addition, the model of Richardson (2006) also includes leverage, the level of cash, firm age, firm size, return on assets and prior firm level investment, which are also the determinants of investment decision. Following Richardson (2006) ${ }^{[33]}$, to control for the effect of unobservable firm characteristics on new investment expenditures, we employ the fixed effects regression models to estimate Model (1). The residuals from the regression model reflect the deviation from the expected investment level, and we use these residuals as a firm-specific proxy for inefficient investment. One of our proxy variables for inefficient investment (InEffInv) is the absolute value of the residuals, and higher value means higher level of inefficient investment.

\section{Independent Variables}

Our paper employs two important independent variables to test the hypotheses. First, following Devos et al. (2012) and Strebulaev and Yang (2013), we define the variable of zero-leverage policy $(Z L)$ as a dummy variable taking the value of 1 if a firm has zero book leverage in a given year and 0 otherwise. Book leverage is measured by the ratio of the sum of short-term and long-term liabilities to total assets. And the book leverage of firms adopting zero-leverage policy equals zero.

Second, following Lin et al. (2011) and Cornett et al. (2007), we utilize the number of shares held by all institutional investors divided by the total number of shares outstanding as our measurement for institutional ownership (InstiOwnership). Considering institutional ownership an external monitoring mechanism, higher institutional ownership can reflect better corporate governance. Consistent with this view, Nikolov and Whited 
(2010) suggest that measurements based on institutional ownership are less noisy proxies for governance than governance indices.

\section{Control Variables}

Following previous studies, we introduce several control variables in our models. As for the proxy for firm size, we use the natural logarithm of total assets (Logsize). $C F$ is the ratio of the net cash flow generated from operating activities divided by initial book assets, which provides a firm with financial resources for investment. The variable Cent 10 represents the ratio of the sum of the second to the tenth largest shareholder holding shares to the capital in order to capture a balance of ownership structure from other controlling shareholders. We also control for a firm's listing age (Lnage). The longer the firm has been listed, the more likely it is to be in maturity, suggesting reduced investment activity. RevGrowth is measured as sales growth. To measure firms' investment opportunities we include the ratio of market to book value of assets (TobinQ). Finally, we add dummy variables to control for year and industry effects (Year dummies and Industry dummies). Table 1 provides a summary and the definitions of the key variables used in this study.

\section{Model Specification}

The Model (2) we propose to test the effect of zero-leverage policy without bank creditors on inefficient investments is as follows:

$$
\begin{aligned}
& \text { InEffIn }_{i, t}=\alpha_{0}+\alpha_{1} Z_{i, t}+\alpha_{2} \mathrm{CF}+\alpha_{3} \text { Logsize }_{i, t}+\alpha_{4}{\text { Cent } 10_{i, t}} \\
& +\alpha_{5}{\text { Tangibility }+\alpha_{6} \operatorname{Re} v \text { Growth }}_{i, t}+\alpha_{7} \text { TobinQ }_{i, t}+\alpha_{8} \text { ROA }_{i, t} \\
& +\alpha_{9} \text { Lnage }_{i, t}+\alpha_{10} \operatorname{MngHld}_{i, t}+\sum \text { Year }+\sum \text { Industry }+\varepsilon_{i, t}
\end{aligned}
$$

where the dependent variable InEffInv represents inefficient investments. $Z L$ is a dummy variable set to one if the firm is without bank creditors and zero otherwise. Since our Hypotheses 1 conjectures that zero-leverage policy could increase inefficient investment, we expect $\alpha_{1}$ to be positive. The rest are control variables that may influence inefficient investment, including CF, Logsize, Cent10, Tangibility, RevGrowth, TobinQ, ROA, Lnage, MngHld, year dummies and industries dummies. 
Table 1. Description of variables.

\begin{tabular}{l|l}
\hline \multicolumn{1}{c|}{ Variable } & \multicolumn{1}{c}{ Description } \\
\hline InEffInv & $\begin{array}{l}\text { The absolute value of the residuals in the expected investment model according to Richardson (2006) } \\
\text { outstanding }\end{array}$ \\
\hline InstiOwnership & $\begin{array}{l}\text { A dummy variable taking the value of 1 if a firm has a zero book leverage in a given year and 0 } \\
\text { otherwise }\end{array}$ \\
\hline ZL & $\begin{array}{l}\text { Ratio of cash paid to acquire fixed assets, intangible assets and other long-term assets minus net cash } \\
\text { received from the sale of fixed assets, intangible assets and other long-term assets divided by initial } \\
\text { book assets }\end{array}$ \\
\hline Invest & Ratio of market to book value of assets \\
\hline TobinQ & Ratio of liabilities to book assets \\
\hline Lev & Ratio of cash holdings to book assets \\
\hline CashHoldings & Difference between the actual year and a firm's IPO date \\
\hline AGE & Natural logarithm of listing ages \\
\hline Lnage & Ratio of net profit to book assets \\
\hline LOA & Natural logarithm of book assets \\
\hline RevGrowth & Ratio of the sale growth \\
\hline Cent10 & Ratio of the sum of the second to the tenth largest shareholder holding shares to the capital \\
\hline CF & Ratio of the net cash flow generated from operating activities divided by initial book assets \\
\hline Tangibility & Ratio of fixed assets to book assets \\
\hline MngHld & Ratio of the management holding shares to the capital \\
\hline Year & Year dummies \\
\hline Industry & Industry dummies \\
\hline &
\end{tabular}

\section{RESULTS AND DISCUSSION}

\section{Descriptive Statistics Analysis}

Table 2 reports the distribution of zero-leverage firms by time. The results reveal that over the period of 2000-2013, 12.73\% of the firm-year observations have zero debt, including short-term and long-term debt. More than one third $(36.38 \%)$ of Chinese firms have zero leverage for at least one period from 2000 to 2013. Compared to US evidence (Strebulaev and Yang, 2013), the proportion of zero-leverage firms in China is slightly larger. Table 2 reveals the considerable variation of the proportion of zero-leverage firms over time. This proportion averages at $6.03 \%$ over the period of 2000-2006, but increases henceforth, rising sharply to $16.86 \%$ over the period $2007-2013$. It shows that extremely conservative debt policies have prevailed in recent years around the world (Bessler et al., 2013). A similar trend is documented in contemporaneous US research (Devos et al., 2012).

Table 2. Distribution of zero-leverage firms by time.

\begin{tabular}{l|ccc|ccc}
\hline & \multicolumn{2}{|c}{ Number of firm-year observations } & \multicolumn{3}{c}{ Number of firms } \\
\hline \multicolumn{1}{c|}{ Periods } & All sample & ZL & \% & All sample & ZL & \% \\
\hline $2000-2006$ & 8817 & 532 & $6.03 \%$ & 1482 & 215 & $14.51 \%$ \\
$2007-2013$ & 14334 & 2416 & $16.86 \%$ & 2538 & 851 & $33.53 \%$ \\
$2007-2013$ & 12023 & 1656 & $13.77 \%$ & 2358 & 663 & $28.12 \%$ \\
(Sample Data) & 23151 & 2948 & $12.73 \%$ & 2595 & 944 & $36.38 \%$ \\
$2000-2013$ & & &
\end{tabular}

Note: This table summarizes the distribution of zero-leverage $(Z L)$ firms by time, and lists the number and percentage of firms that have a ZL status (i.e., firms that have zero leverage) in a given year. 
Table 3. Descriptive statistics for zero-leverage firms and leverage firms.

\begin{tabular}{|c|c|c|c|c|c|c|c|c|}
\hline \multirow[b]{2}{*}{ Variables } & \multicolumn{3}{|c|}{ Leverage firms } & \multicolumn{3}{|c|}{ Zero-leverage firms } & \multicolumn{2}{|c|}{ Tests } \\
\hline & Observations & Mean1 & Median1 & Observations & Mean2 & Median2 & MeanDiff & Chi2 \\
\hline InEffInv & 10367 & 0.0628 & 0.0480 & 1656 & 0.0831 & 0.0800 & $-0.0203 * * *$ & $281.622 * * *$ \\
\hline Invest & 10367 & 0.0723 & 0.0470 & 1656 & 0.0503 & 0.0290 & $0.0221 * * *$ & $104.271 * * *$ \\
\hline TobinQ & 10359 & 2.404 & 1.856 & 1654 & 3.748 & 2.738 & $-1.3434 * * *$ & $322.429^{* * *}$ \\
\hline ZL & 10367 & 0 & 0 & 1656 & 1 & 1 & -1 & $1.2 \mathrm{e}+04 * * *$ \\
\hline Invest & 10367 & 0.0723 & 0.0470 & 1656 & 0.0503 & 0.0290 & $0.0221 * * *$ & $104.271 * * *$ \\
\hline $\mathrm{CF}$ & 10367 & 0.0476 & 0.0460 & 1656 & 0.0675 & 0.0590 & $-0.0199 * * *$ & $30.339 * * *$ \\
\hline RevGrowth & 10346 & 0.226 & 0.126 & 1635 & 0.238 & 0.116 & -0.0119 & 1.426 \\
\hline Logsize & 10364 & 21.91 & 21.77 & 1656 & 21.28 & 20.96 & $0.6310 * * *$ & $355.040 * * *$ \\
\hline Cent10 & 10365 & 0.186 & 0.166 & 1656 & 0.234 & 0.224 & $-0.0480 * * *$ & $96.988^{* * *}$ \\
\hline Tangibility & 10322 & 0.950 & 0.967 & 1506 & 0.955 & 0.974 & $-0.0053 * * *$ & $36.912 * * *$ \\
\hline ROA & 10362 & 0.0296 & 0.0300 & 1656 & 0.0571 & 0.0540 & $-0.0275 * * *$ & $172.303 * * *$ \\
\hline Lnage & 10367 & 2.215 & 2.413 & 1656 & 1.950 & 2.150 & $0.2655 * * *$ & $43.656^{* * *}$ \\
\hline InstiOwnership & 10285 & 0.360 & 0.350 & 1647 & 0.346 & 0.312 & $0.0144 * *$ & $9.642 * * *$ \\
\hline MngHld & 10309 & 0.0491 & 0 & 1640 & 0.116 & 0 & $-0.0668 * * *$ & $6.569 * *$ \\
\hline
\end{tabular}

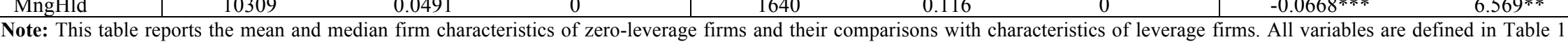
The last two columns present ' $t$-value' from two-sample t-test and the ' $Z$-values' from the Wilcoxon rank sum test (difference between zero-leverage firms and leverage firms). ${ }^{* * *}$ denote the parameters are significant at the $1 \%$ level. $* *$ denote the parameters are significant at the $5 \%$ level. * denote the parameters are significant at the $10 \%$ level. 
We exclude firms with missing financial data and firms in Financial industry from our sample and finally get an unbalanced panel data of 2358 Chinese listed firms over the period 2007 to 2013 (12023 observations in total). In our sample, the percentage of the firm-year observations with zero leverage has reached to $13.77 \%$. About $28.12 \%$ of Chinese firms have zero leverage from the period of 2007 to 2013, which is slightly lower than the results over the period 2000-2013. It is just the reason why we choose the sample period of 2007 to 2013 rather than the period of 2000 to 2013.

Table 3 presents univariate comparisons of the characteristics of zero-leverage firms and leverage firms. The average inefficient investment for zero-leverage firms is $8 \%$ of total assets, which is significantly higher than the leverage firms, suggesting that zero-leverage policy doesn't help to improve the investment efficiency. The average ownership by the second to the tenth largest shareholder for zero-leverage firms $(23.4 \%)$ is higher than the leverage firms (18.6\%), while the mean institutional ownership is lower for zero-leverage firms (34.6\% vs. $36 \%)$, indicating that leverage firms have higher external monitoring. Consistent with prior studies, zero-leverage firms are smaller (mean Logsize 21.28 vs. 21.92) and younger ( mean Lnage 1.95 vs. 2.215), have higher TobinQ (mean 3.748 vs. 2.404 ) and higher net cash flow ( $C F$ of $6.75 \%$ vs. $4.76 \%$ ), and are more profitable than the leverage firms (Strebulaev and Yang, 2013; Bessler et al., 2013; Devos et al., 2012) .

\section{Correlation Analysis}

Table 4 provides the Pearson correlation matrix. Zero-leverage policy shows significant positive correlations with inefficient investment, indicating that higher level of $Z L$ is associated with higher level of inefficient investment. And the negative relationship between the institutional ownership and zero-leverage policy is similar with the result of descriptive statistics analysis in Table 3. Other control variables are also significantly related to inefficient investment and investment expenditures. Correlations between the independent variables are not high, indicating that collinearity is not likely to be a problem in our study. As correlation results do not control for differences in firm, industry, or year characteristics, we then turn to multivariate analysis.

\section{Multivariate Analysis}

The column (1) of Table 5 reports the results of the effect of firms' zero-leverage policy on inefficient investment. It presents the estimation results of Model (2) using InEffInv as the dependent variable. In order to test our Hypothesis 1 , we include $Z L$ as an explanatory variable that we expect to be positively related to the inefficient investment.

As we expected, the coefficient of $Z L$ in column (1) of Table 5 is positive and significant, indicating that zero-leverage policy increases firms' inefficient investment (we confirm H1), that is, the investment behaviors of zero-leverage firms are distorted heavily in some degree. For our control variables, we find that the sales growth (RevGrowth) has a significantly positive coefficient, showing that a higher ratio of sales growth leads to a higher level of inefficient investment, which is consistent with previous studies (Cutillas Gomariz and Sánchez Ballesta, 2014). Moreover, larger firm, measured by Logsize, is associated with higher inefficient investment. Therefore, the results of Model (2) are consistent with our $\mathrm{H} 1$ that zero-leverage firms without bank creditors show higher level of inefficient investment than leverage firms.

\section{The Increase of Other External Monitoring}

How does the level of other external monitoring influence the sensitivity of zero-leverage policy to inefficient investment? As corporate external monitor, the institutional investor is an important mechanism for controlling managerial behavior and mitigating the agency problems (Bathala et al., 1994). Therefore, we further shed light on this question from the perspective of institutional ownership. 


\begin{tabular}{|c|c|c|c|c|c|c|c|c|c|c|c|c|c|}
\hline & InEffInv & Invest & TobinQ & $\mathbf{Z L}$ & $\begin{array}{c}\text { Insti- } \\
\text { Ownership }\end{array}$ & $\mathbf{C F}$ & Logsize & Cent10 & $\begin{array}{l}\text { Tangi- } \\
\text { bility }\end{array}$ & $\begin{array}{c}\text { Rev- } \\
\text { Growth }\end{array}$ & ROA & Lnage & $\begin{array}{c}\text { Mng- } \\
\text { Hld }\end{array}$ \\
\hline In-EffInv & 1 & & & & & & & & & & & & \\
\hline Invest & $0.538^{* * *}$ & 1 & & & & & & & & & & & \\
\hline TobinQ & $0.169^{* * *}$ & $-0.038^{* * *}$ & 1 & & & & & & & & & & \\
\hline ZL & $0.123^{* * *}$ & $-0.097^{* * *}$ & $0.226^{* * *}$ & 1 & & & & & & & & & \\
\hline $\begin{array}{l}\text { Insti } \\
\text { Owner-ship }\end{array}$ & $0.025^{* * *}$ & $0.073^{* * *}$ & $-0.097^{* * *}$ & $-0.021^{* *}$ & 1 & & & & & & & & \\
\hline $\mathrm{CF}$ & $0.118^{* * *}$ & $0.236^{* * *}$ & $0.077^{* * *}$ & $0.065^{* * *}$ & $0.118^{* * *}$ & 1 & & & & & & & \\
\hline Logsize & $0.055^{* * *}$ & $0.112^{* * *}$ & $-0.509^{* * *}$ & $-0.159^{* * *}$ & $0.422^{* * *}$ & $0.062^{* * *}$ & 1 & & & & & & \\
\hline Cent10 & $0.089^{* * *}$ & $0.134^{* * *}$ & $0.074^{* * *}$ & $0.131^{* * *}$ & $0.131^{* * *}$ & $0.042^{* * *}$ & 0.0120 & 1 & & & & & \\
\hline Tangi-bility & $-0.020^{* *}$ & $-0.097^{* * *}$ & $-0.186^{* * *}$ & $0.030^{* * *}$ & $0.040^{* * *}$ & $-0.086^{* * *}$ & $0.091^{* * *}$ & -0.00300 & 1 & & & & \\
\hline $\begin{array}{l}\text { Rev- } \\
\text { Growth }\end{array}$ & $0.162^{* * *}$ & $0.211^{* * *}$ & $0.056^{* * *}$ & 0.00600 & 0.00600 & $0.150^{* * *}$ & $0.052^{* * *}$ & $0.066^{* * *}$ & 0.00800 & 1 & & & \\
\hline ROA & 0.00700 & $0.151^{* * *}$ & $0.066^{* * *}$ & $0.133^{* * *}$ & $0.199^{* * *}$ & $0.296^{* * *}$ & $0.106^{* * *}$ & $0.123^{* * *}$ & $0.047^{* * *}$ & $0.180^{* * *}$ & 1 & & \\
\hline Lnage & $-0.020^{* *}$ & $-0.200^{* * *}$ & -0.0110 & $-0.142^{* * *}$ & $0.084^{* * *}$ & $-0.031^{* * *}$ & $0.104^{* * *}$ & $-0.373^{* * *}$ & $-0.038^{* * *}$ & 0.0100 & $-0.118^{* * *}$ & 1 & \\
\hline MngHld & $-0.033^{* * *}$ & $0.096^{* * *}$ & $0.044^{* * *}$ & $0.154^{* * *}$ & $-0.225^{* * *}$ & $-0.022^{* *}$ & $-0.171^{* * *}$ & $0.354^{* * *}$ & $0.026^{* * *}$ & -0.00100 & $0.099^{* * *}$ & $-0.567^{* * *}$ & 1 \\
\hline
\end{tabular}

Note: This table reports the Pearson correlation matrix. All variables are defined in Table $1 .{ }^{* * *}$ denote the parameters are significant at the $1 \%$ level. $* *$ denote the parameters are significan at the $5 \%$ level. * denote the parameters are significant at the $10 \%$ level. 
Table 5. Institutional ownership and the effect of zero-leverage policy on inefficient investment

\begin{tabular}{|c|c|c|}
\hline \multirow{2}{*}{ VARIABLES } & \multicolumn{2}{|c|}{ InEffInv } \\
\hline & (1) & (2) \\
\hline \multirow{2}{*}{ ZL } & $0.0142 * * *$ & $0.0313 * * *$ \\
\hline & $(0.00162)$ & $(0.00256)$ \\
\hline \multirow{2}{*}{ InstiOwnership } & & -0.00383 \\
\hline & & $(0.00272)$ \\
\hline \multirow{2}{*}{ ZL*InstiOwnership } & & $-0.0517 * * *$ \\
\hline & & $(0.00598)$ \\
\hline \multirow{2}{*}{$\mathrm{CF}$} & $0.0389 * * *$ & $0.0424 * * *$ \\
\hline & $(0.00520)$ & $(0.00520)$ \\
\hline \multirow{2}{*}{ Logsize } & $0.00563 * * *$ & $0.00633^{* * *}$ \\
\hline & $(0.000498)$ & $(0.000530)$ \\
\hline \multirow{2}{*}{ Cent10 } & $0.0294 * * *$ & $0.0326^{* * *}$ \\
\hline & $(0.00440)$ & $(0.00450)$ \\
\hline \multirow{2}{*}{ Tangibility } & $0.0299 * * *$ & $0.0357 * * *$ \\
\hline & $(0.00883)$ & $(0.00883)$ \\
\hline \multirow{2}{*}{ RevGrowth } & $0.0123 * * *$ & $0.0117 * * *$ \\
\hline & $(0.000775)$ & $(0.000776)$ \\
\hline \multirow{2}{*}{ TobinQ } & $0.00690 * * *$ & $0.00712 * * *$ \\
\hline & $(0.000319)$ & $(0.000322)$ \\
\hline \multirow{2}{*}{$\mathrm{ROA}$} & $-0.0685 * * *$ & $-0.0640 * * *$ \\
\hline & $(0.00772)$ & $(0.00781)$ \\
\hline \multirow{2}{*}{ Lnage } & $-0.00182 *$ & $-0.00201 * *$ \\
\hline & $(0.00100)$ & $(0.00100)$ \\
\hline \multirow{2}{*}{ MngHld } & $-0.0155 * * *$ & $-0.0226 * * *$ \\
\hline & $(0.00432)$ & $(0.00453)$ \\
\hline \multirow{2}{*}{ Constant } & $-0.124 * * *$ & $-0.142 * * *$ \\
\hline & $(0.0143)$ & $(0.0147)$ \\
\hline Year dummies & Yes & Yes \\
\hline Industry dummies & Yes & Yes \\
\hline Observations & 11,712 & 11,631 \\
\hline R-squared & 0.132 & 0.138 \\
\hline
\end{tabular}

Note: This table presents the regression results on the effect of institutional ownership on the relationship between zero-leverage policy and inefficient investment. The sample consists of unbalanced panel data in China during the period from 2007 to 2013 . The dependent variable is InEffInv. All variables are defined in Table 1 . The standard errors are in parentheses. *, **, and *** denote significance at the $10 \%, 5 \%$, and $1 \%$ levels, respectively.

Table 5 reports the regression results of the effect of institutional ownership on the relation between zeroleverage policy and inefficient investment in column (2). We include institutional ownership and the interaction terms between institutional ownership and zero-leverage policy in Model (2) and re-estimate the inefficient investment model. The coefficient of institutional ownership variable is negative in column (2) but not significant, indicating that the institutional ownership has negative effect on inefficient investment. Moreover, our results in column (2) show that the coefficient of $Z L^{*}$ InstiOwnership is negative and statistically significant, suggesting that, ceteris paribus, the relationship between zero-leverage policy and inefficient investment is weaker for those firms with higher institutional ownership (we confirm Hypothesis 2). Consistent with prior literatures (Chung and Zhang, $2011^{[12]}$; Bathala et al., $1994^{[5]}$ ), these findings imply that institutional investors, as external monitors, can play a useful role in limiting agency problems. The sensitivity between zero-leverage policy and inefficient investment might be lower in firms with higher level of institutional ownership because of the external monitoring by institutional investors.

Therefore, the results are consistent with our Hypothesis 2 that the sensitivity between zero-leverage policy and inefficient investment becomes weaker when other external monitoring increases. 


\section{ROBUSTNESS TESTS}

In this section, we use the alternative investment efficiency model, sample processing using propensityscore matching and the re-estimation of main variables to evaluate the robustness of the empirical findings.

\section{Alternative Investment Efficiency Model}

We estimate the sensitivity of investment expenditure to investment opportunities (Tobin's $Q$ ) as another measurement of investment efficiency as shown in Model (3) (e.g., Chen et al., 2011 $1^{[11]}$ ).

$$
\begin{aligned}
& \text { Invest }_{i, t}=\alpha_{0}+\alpha_{1} \text { TobinQ }_{i, t-1}+\alpha_{2} Z L_{i, t}+\alpha_{3} \text { TobinQ }_{i, t-1} * Z L_{i, t} \\
& +\alpha_{4} \text { ControlVariables }+\sum \text { Year }+\sum \text { Industry }+\varepsilon
\end{aligned}
$$

where the dependent variable Invest is a firm's new investment expenditure. TobinQ represents investment opportunities, which is measured as the sum of market value of equity and liabilities divided by book value of total assets. Consistent with the literature, we include several control variables in Model (3), such as CF, Logsize, Cent10, Tangibility, RevGrowth, Markettobook, ROA, Lnage and MngHld. ZL variable is used to distinguish the effects of zero-leverage policy on investment expenditure. We test our hypotheses by examining the interaction between Tobin $Q$ and $Z L$. For all sample firms, we expect the coefficient of Tobin $Q^{*} Z L$ to be significantly less than zero.

Table 6 reports the results of the effect of firms' zero-leverage policy on the sensitivity of investment expenditure to investment opportunities. We use the model of the sensitivity of investment expenditure to investment opportunities (Tobin's $Q$ ) to test our Hypothesis 1 (e.g., Chen et al., 2011 ${ }^{[11]}$ ). We examine whether the coefficient on interaction term between Tobin $Q$ and $Z L$ is significantly less than zero. The sensitivity of investment expenditure to investment opportunities is positive and significant in column (1), which is consistent with the prior literatures. However, the coefficient of the interaction term Tobin $Q^{*} Z L$ is significantly negative, indicating that the sensitivity would be reduced in zero-leverage firms. It suggests that zero-leverage policy is more useful to reduce investment efficiency. Therefore, the results of Model (3) using this inefficient investment proxy are similar to those previously reported, as displayed in Table 5. 
Table 6. The effects of firms' zero-leverage policy on the sensitivity of investment expenditure to investment opportunities

\begin{tabular}{|c|c|c|}
\hline \multirow{2}{*}{ VARIABLES } & \multicolumn{2}{|c|}{ Invest } \\
\hline & (1) & (2) \\
\hline TobinQ & $\begin{array}{c}0.00373 * * * \\
(0.000419)\end{array}$ & $\begin{array}{c}0.00582 * * * \\
(0.000490)\end{array}$ \\
\hline ZL & & $\begin{array}{c}-0.00989 * * * \\
(0.00343)\end{array}$ \\
\hline ZL*TobinQ & & $\begin{array}{c}-0.00413 * * * \\
(0.000762)\end{array}$ \\
\hline $\mathrm{CF}$ & $\begin{array}{l}0.115^{* * *} \\
(0.00681) \\
\end{array}$ & $\begin{array}{l}0.119 * * * \\
(0.00678)\end{array}$ \\
\hline Logsize & $\begin{array}{l}0.0114 * * * \\
(0.000623)\end{array}$ & $\begin{array}{l}0.0106 * * * \\
(0.000631)\end{array}$ \\
\hline Cent10 & $\begin{array}{l}0.0350 * * * \\
(0.00577)\end{array}$ & $\begin{array}{c}0.0339 * * * \\
(0.00573)\end{array}$ \\
\hline Tangibility & $\begin{array}{c}-0.104 * * * \\
(0.0115)\end{array}$ & $\begin{array}{c}-0.0909 * * * \\
(0.0115)\end{array}$ \\
\hline RevGrowth & $\begin{array}{c}0.0192 * * * \\
(0.00103) \\
\end{array}$ & $\begin{array}{c}0.0185^{* * *} \\
(0.00103)\end{array}$ \\
\hline ROA & $\begin{array}{c}0.0243^{* *} \\
(0.0101)\end{array}$ & $\begin{array}{c}0.0349 * * * \\
(0.0101)\end{array}$ \\
\hline Lnage & $\begin{array}{c}-0.0243^{* * *} \\
(0.00132)\end{array}$ & $\begin{array}{c}-0.0247 * * * \\
(0.00131)\end{array}$ \\
\hline MngHld & $\begin{array}{c}-0.000230 \\
(0.00567)\end{array}$ & $\begin{array}{c}0.00137 \\
(0.00564)\end{array}$ \\
\hline Constant & $\begin{array}{c}-0.0528 * * * \\
(0.0178)\end{array}$ & $\begin{array}{c}-0.0579 * * * \\
(0.0182)\end{array}$ \\
\hline $\begin{array}{l}\text { Year dummies } \\
\text { Industry dummies } \\
\text { Observations } \\
\text { R-squared }\end{array}$ & $\begin{array}{c}\text { Yes } \\
\text { Yes } \\
11,716 \\
0.216\end{array}$ & $\begin{array}{c}\text { Yes } \\
\text { Yes } \\
11,716 \\
0.226\end{array}$ \\
\hline
\end{tabular}

Note: This table reports OLS regression results of the Model (3). The dependent variables are Invest. All variables are defined in the Table 1 . The standard errors are in parentheses. *,**, and *** denote significance at the $10 \%, 5 \%$, and $1 \%$ levels, respectively.

\section{Sample Processing Using Propensity-Score Matching}

In order to reduce the potential for "overt bias" between zero-leverage firms and leverage firms, we employ a propensity-score matched-pair research design to choose paired sample according to Armstrong et al. $(2010)^{[3]}$. The propensity-score method forms matched pairs of zero-leverage firm-years that have similar firm-level characteristics but different levels of leverage. This approach alleviates misspecification that occurs. In this study, we match our matched-pairs sample on four variables of firm size, market to book ratio, ratio of net profit to book assets and ratio of cash holding to book assets. Adding year and industry into the process of matching makes matching variables increase largely, which leads to that the matched results is difficult to satisfy the equilibrium conditions. As a result, we match our paired sample by year. 
Table 7. Institutional ownership and the effects of zero-leverage policy on inefficient investment using matched-pairs sample

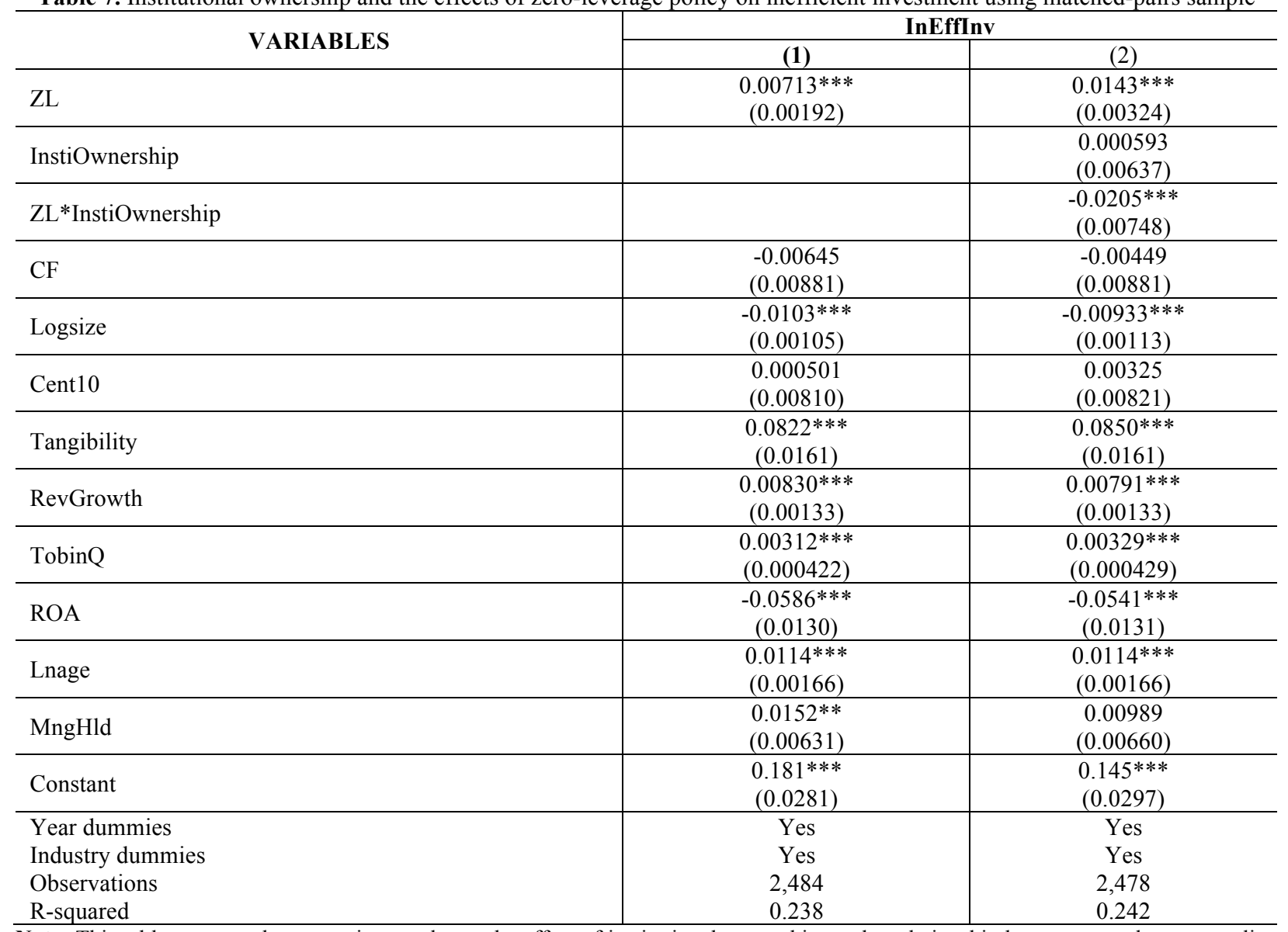

Note: This table presents the regression results on the effect of institutional ownership on the relationship between zero-leverage policy and inefficient investment. The propensity-score matching algorithm yields a primary analysis sample of 2683 zero-leverage-firm-year observations (1654 matched pairs). The dependent variable is InEffInv. All variables are defined in Table 1. The standard errors are in parentheses. ${ }^{* *}$, and $* * *$ denote significance at the $10 \%, 5 \%$, and $1 \%$ levels, respectively.

Table 7 reports the results of institutional ownership and the effects of zero-leverage policy on inefficient investment using matched-pairs sample. As we expected, the coefficients of $Z L$ and $Z L *$ InstiOwnershi in column (1) and (2) are similar to those previously reported, as displayed in Table 5, which accords with our hypothesis 1 and hypothesis 2. Overall, zero-leverage firms without bank creditors increase inefficient investment, and the effect of zero-leverage policy on inefficient investment will be mitigated by other external monitoring.

\section{Main Variables Re-Estimation}

Since zero-leverage policy variable is the central components of the model, we reconsider and calculate our aggregate measurement of zero-leverage policy. Because the definition of zero-leverage policy in this paper is that book leverage (the ratio of the sum of short-term and long-term liabilities to total assets) equals to zero. However, in order to avoid the leverage effect of bonds on the empirical results, we redefine the variable of book leverage as the ratio of the sum of short-term, long-term liabilities and bonds to total assets. With this approach, we aim to solve the inaccurate classification of zero-leverage policy and assess the robustness of results with variables that reflect the tendency of the firm's zero-leverage policy.

Taking these alternative specifications into consideration, the results (unreported) are consistent with our predictions. Zero-leverage firms without bank creditors show higher level of inefficient investment and the institutional ownership could mitigate the sensitivity between zero-leverage policy and inefficient investment. 


\section{CONCLUSIONS}

In this paper, we present evidence about the impact of zero-leverage policy on firms' investment behavior in a sample of non-financial firms in China from 2007 to 2013. We first analyze the effect of zero-leverage policy on inefficient investment from the perspective of the lack of bank creditors and find that the inefficient investment problem is significantly more serious for zero-leverage firms than those for leverage firms. Second, we further examine the effect of other external monitoring on the sensitivity between zero-leverage policy and inefficient investment. The empirical results show that the sensitivity between zero-leverage policy and inefficient investment is mitigated by other external monitoring such as institutional ownership, which is consistent with our conjecture that other external monitoring helps control the inefficient investment caused by the lack of bank creditors. Therefore, we conclude that zero-leverage policy without bank creditors in China increases inefficient investment.

While the related studies focus on analyzing the increasing prevalence of zero-leverage behavior in general, we explicitly analyze the effect of zero-leverage policy on firms' investment behaviors from the perspective of lack of bank creditors. Moreover, we are the first to show that zero-leverage policy can increase inefficient investment. Our findings also have implications for a growing literature on the economic consequence of zero-leverage policy. We not only show new evidence about the role of zero-leverage policy without bank creditor monitoring in resource allocation, but also provide further evidence that the increase of other external monitoring indeed mitigate the influence of inefficient investment caused by the absence of bank creditor monitoring. These evidences enhance our understanding of firm's zero-leverage policy and the important monitoring role of bank creditors in general.

\section{ACKNOWLEDGEMENTS}

This research is financially supported by the Social Sciences Research Project of Ministry of Education [no. 14XJC790001].

\section{AUTHOR INFORMATION}

Dr. Wanli Li is a professor of accounting in the School of Management at Xi' an Jiaotong University and School of Accounting at Shanghai University of International Business and Economics. Her main research interests include accounting restatements, earnings management, corporate governance and political connections. Wanli Li, Mailing address: No.28, Xianning West Road, Xi’an, Shaanxi, 710049, P.R. China. E-mail: 1wlxitu@126.com

Zhen Huang is a Ph.D. candidate of accounting in the School of Management at Xi'an Jiaotong University. Her main research interests include corporate governance, corporate finance and corporate investment. Zhen Huang, School of Management; The Key Lab of the Ministry of Education for process control \& Efficiency Engineering, Xi'an Jiaotong University, Xi'an, China. Mailing address: Mailbox 1810, No.28, Xianning West Road, Xi'an, Shaanxi, 710049, P.R. China. E-mail: hzxjtu@163.com (Corresponding author). Tel: +86 18392186412

Weiwei Gao is a Ph.D. candidate of accounting in the School of Management at Xi'an Jiaotong University. Her main research interests include corporate governance and corporate finance. Weiwei Gao, School of Management; The Key Lab of the Ministry of Education for process control \& Efficiency Engineering, Xi'an Jiaotong University, Xi'an, China. Mailing address: Mailbox 1851, No.28, Xianning West Road, Xi'an, Shaanxi, 710049, P.R. China. Email: gwwsmile 0913@126.com

\section{REFERENCES}

Ahn, S., \& Choi, W. (2009). The role of bank monitoring in corporate governance: evidence from borrowers's earnings management behavior. Journal of banking \& finance, 33 (2), 425-434.

Ang, J. S., Cole, R. A., \& Lin, J. W. (2000). Agency costs and ownership structure. the Journal of Finance, 55 (1), $81-106$.

Armstrong, C. S., Jagolinzer, A. D., \& Larcker, D. F. (2010). Chief executive officer equity incentives and accounting irregularities. Journal of Accounting Research, 48 (2), 225-271.

Bathala, C. T., Moon, K. P., \& Rao, R. P. (1994). Managerial ownership, debt policy, and the impact of institutional holdings: An agency perspective. Financial Management, 38-50.

Bathala, C. T., Moon, K. P., \& Rao, R. P. (1994). Managerial ownership, debt policy, and the impact of institutional holdings: An 
agency perspective. Financial Management, 38-50.

Bessler, W., Drobetz, W., Haller, R., \& Meier, I. (2013). The international zero-leverage phenomenon. Journal of Corporate Finance, 23 (12), 196-221.

Biddle, G. C., Hilary, G., \& Verdi, R. S. (2009). How does financial reporting quality relate to investment efficiency? Journal of Accounting and Economics, 48 (2), 112-131.

Brealey, R., Leland, H. E., \& Pyle, D. H. (1977). Informational asymmetries, financial structure, and financial intermediation. The journal of Finance, 32 (2), 371-387.

Byers, S. S., Fields, L. P., \& Fraser, D. R. (2008). Are corporate governance and bank monitoring substitutes: Evidence from the perceived value of bank loans. Journal of Corporate Finance, 14 (4), 475-483.

CAMPBEL, T. S., \& Kracaw, W. A. (1980). Information production, market signalling, and the theory of financial intermediation. The Journal of Finance, 35 (4), 863-882.

Chen, S., Sun, Z., Tang, S., \& Wu, D. (2011). Government intervention and investment efficiency: Evidence from China. Journal of Corporate Finance, 17 (2), 259-271.

Chung, K. H., \& Zhang, H. (2011). Corporate governance and institutional ownership. Journal of Financial and Quantitative Analysis, 46 (01), 247-273.

Cornett, M. M., Marcus, A. J., Saunders, A., \& Tehranian, H. (2007). The impact of institutional ownership on corporate operating performance. Journal of Banking \& Finance, 31 (6), 1771-1794.

Cutillas Gomariz, M. F., \& Sánchez Ballesta, J. P. (2014). Financial reporting quality, debt maturity and investment efficiency. Journal of Banking \& Finance, 40 (3), 494-506.

Devos, E., Dhillon, U., Jagannathan, M., \& Srinivasan, K. (2012). Why are firms unlevered. Journal of Corporate Finance, 18 (3), 664-682.

Dewatripont, M., \& Tirole, J. (1994). A theory of debt and equity: Diversity of securities and manager-shareholder congruence. The Quarterly Journal of Economics, 109 (4), 1027-1054.

Diamond, D. W. (1984). Financial intermediation and delegated monitoring. The Review of Economic Studies, 51 (3), 393-414.

Fama, E. F. (1985). What's different about banks? Journal of monetary economics, 15 (1), 29-39.

Gillan, S. L., \& Starks, L. T. (2000). Corporate governance proposals and shareholder activism: The role of institutional investors. Journal of financial Economics, 57 (2), 275-305.

Gilson, S. C., John, K., \& Lang, L. H. (1990). Troubled debt restructurings: An empirical study of private reorganization of firms in default. Journal of financial economics, 27 (2), 315-353.

Hadlock, C. J., \& James, C. M. (2002). Do banks provide financial slack? the Journal of Finance, 57 (3), $1383-1419$.

Harvey, C. R., Lins, K. V., \& Roper, A. H. (2004). The effect of capital structure when expected agency costs are extreme. Journal of Financial Economics, 74 (1), 3-30.

Hope, O. K., \& Thomas, W. B. (2008). Managerial empire building and firm disclosure. Journal of Accounting Research, 46 (3), 591-626.

Hovakimian, G. (2011). Financial constraints and investment efficiency: Internal capital allocation across the business cycle. Journal of Financial Intermediation, 20 (2), 264-283.

James, C., \& Smith, D. C. (2000). Are Banks Still Special? New Evidence on Their Role in the Corporate Capital-Raising Process. Journal of Applied Corporate Finance, 13 (1), 52-63.

Jensen, M. C. (1986). Agency costs of free cash flow, corporate finance, and takeovers. The American Economic Review, 76 (2), 323-329.

Jensen, M. C., \& Meckling, W. H. (1976). Theory of the firm: Managerial behavior, agency costs and ownership structure. Journal of financial economics, 3 (4), 305-360.

Kang, J., \& Liu, W. (2008). Bank incentives and suboptimal lending decisions: Evidence from the valuation effect of bank loan announcements in Japan. Journal of Banking \& Finance, 32 (6), 915-929.

Lin, C., Ma, Y., \& Xuan, Y. (2011). Ownership structure and financial constraints: Evidence from a structural estimation. Journal of Financial Economics, 102 (2), 416-431.

Nikolov, B., \& Whited, T. (2010). Agency conflicts and cash: Estimates from a structural model. Unpublished working paper. University of Rochester.

Paligorova, T., \& Xu, Z. (2012). Complex ownership and capital structure. Journal of Corporate Finance, 18 (4), $701-716$.

Qian, M., \& Yeung, B. Y. (2014). Bank financing and corporate governance. Journal of Corporate Finance (forthcoming).

Richardson, S. (2006). Over-investment of free cash flow. Review of Accounting Studies, 11 (2-3), 159-189.

Shepherd, J., Tung, F., \& Yoon, A. (2008). What Else Matters for Corporate Governance? The Case of Bank Monitoring. Boston University Law Review (forthcoming), 8-35.

Shleifer, A., \& Vishny, R. W. (1986). Large shareholders and corporate control. The Journal of Political Economy, 461-488.

Strebulaev, I. A., \& Yang, B. (2013). The mystery of zero-leverage firms. Journal of Financial Economics, 109 (1), 1-23.

Stulz, R. (1990). Managerial discretion and optimal financing policies. Journal of financial Economics, 26 (1), 3-27.

Wang, Y., \& Xia, H. (2014). Do Lenders Still Monitor When They Can Securitize Loans? Review of Financial Studies (forthcoming).

Zwiebel, J. (1996). Dynamic capital structure under managerial entrenchment. The American Economic Review, 1197-1215. 